\title{
Handling of informed consent and patient inclusion in research with geriatric trauma patients - a matter of protection or disrespect?
}

This article was published in the following Dove Medical Press journal:

Clinical Interventions in Aging

\author{
Jana S Jensen ${ }^{1, *}$ \\ Stella Reiter-Theil2,* \\ Diana A Celio ${ }^{3}$ \\ Marcel Jakob' \\ Werner Vach' \\ Franziska J Saxer ${ }^{1}$ \\ 'Department of Orthopaedic and \\ Trauma Surgery, University Hospital \\ Basel, Basel 403I, Switzerland; \\ ${ }^{2}$ Department of Clinical Ethics, \\ University Hospital Basel/Psychiatric \\ Hospitals of the University Basel, \\ Basel 4012, Switzerland; ${ }^{3}$ Department \\ for Visceral, Thoracic and Vascular \\ Surgery, Triemli Hospital, Zürich 8063, \\ Switzerland \\ *These authors contributed equally \\ to this work
}

Background: Despite the aging of numerous societies and future health care challenges, clinical research in the elderly is underrepresented. The aim of this review was to analyze the current practice exemplary in gerontotraumatology and to discuss potential improvements.

Materials and methods: A literature review was performed in 2016 based on a PubMed search for gerontotraumatologic studies published between 2005 and 2015. Trials were evaluated for methodology and ethical and age-related aspects.

Results: The search revealed 649 articles, 183 of which met the inclusion criteria. The age range for inclusion was heterogeneous; one-third of trials included patients $<65$ years and only $11 \%$ excluded very elderly. Seventy-four trials excluded patients with typical comorbidities, with 55\% of these without stating scientific reasons. Frailty was assessed in 94 trials and defined as the exclusion criterion in 66 of them. Informed consent (IC) was reportedly obtained in 144 trials; descriptions of the IC process mostly remained vague. Substitute decision making was described in 19 trials; the consenting party remained unclear in 45 articles. Diagnosed dementia was a primary exclusion criterion in $31 \%$ of the trials. Seventeen trials assessed decisional capacity before inclusion, with six using specific assessments.

Conclusion: Many trials in gerontotraumatology exclude relevant subgroups of patients, and thus risk presenting biased estimates of the relevant treatment effects. Exclusion based on age, cognitive impairment, or other exhaustive exclusion criteria impedes specific scientific progress in the treatment of elderly patients. Meaningful trials could profit from a staged, transparent approach that fosters shared decision making. Rethinking current policies is indispensable to improve treatment and care of elderly trauma patients and to protect study participants and researchers alike.

Keywords: systematic review, orthogeriatric, gerontotraumatology, informed consent, clinical research ethics, decisional capacity

\section{Introduction}

Despite rising patient numbers, clinical research in elderly patients is underrepresented; ${ }^{1-6}$ some important treatment approaches have even not been evaluated at all in the elderly. ${ }^{4,5,7}$ Reaching high-level evidence by means of clinical studies is challenging in surgery in general, 8,9 and when elderly patients are involved, the obstacles seem potentiated, especially with respect to obtaining legitimate informed consent (IC).

Correspondence: Franziska J Saxer Department of Orthopaedic and Trauma Surgery, University Hospital Basel, Spitalstrasse 2I, Basel 403I, Switzerland Tel +4I 6I 3286243

Email franziska.saxer@usb.ch

\section{Historical background}

The current attitude toward research in humans is based on relatively new developments. Following the Hippocratic tradition and Percival's Medical Ethics, deliberate 
nondisclosure has long been practiced. ${ }^{10-13}$ For medical treatment, the imperative for consent was only determined in the 20th century ("every human being of adult years and sound mind has a right to determine what shall be done with his own body"). ${ }^{14}$

The "Berlin Codex" of 1901, ${ }^{15}$ by contrast, is the first legally binding document that enforces consent for research; in addition, it specifically prohibits research in vulnerable populations and defines responsibilities for the compliance with these requirements. This governmental directive was issued as reaction to a research project in which prostitutes were unknowingly treated against syphilis with serum from recovering syphilis patients. The result was an epidemic of syphilis among the prostitutes and, most probably, their clients.

The doctrine of IC per se was formulated in the late 1940s in the Nuremberg Code ${ }^{16,17}$ as reaction to the atrocities in the name of scientific progress during the Nazi regime. The Nuremberg Code roughly outlined the basic principles of research ethics that were established in more detail for the Declaration of Helsinki (DoH) of $1964 .{ }^{18}$ Unlike the Berlin Codex, however, these guidelines had no legal status, thus rendering the prevention or ban of questionable practice difficult. Beecher ${ }^{19}$ and Pappworth ${ }^{20}$ have both published reports about - from our present perspective - unbelievable cases of scientific misconduct in US health care institutions. Some of the studies were even approved by the regulatory authorities, as, for instance, the Tuskegee experiment: in this long-term observational study that was started in 1932, approximately 400 men suffering from syphilis were not adequately treated (even after the benefit of penicillin had been broadly accepted), in order to evaluate the natural course of the disease. Even in a re-evaluation in 1969, the Centers for Disease Control and Prevention reaffirmed the need for a continuation of the study. The study was only stopped 2 years later after a public outcry. ${ }^{21}$ This incident led to the implementation of the National Research Act in 1974, ${ }^{22}$ and consequently, the Belmont Report ${ }^{23}$ that defines the following three basic ethical principles to guide research practice:

1. Respect for persons

2. Beneficence

3. Justice.

This development and the implementation of institutional review boards and competent ethics committees coincided with the establishment of Good Clinical Practice (GCP) guidelines $^{24}$ that were embedded both in the Code of Federal Regulations in $1980^{25}$ and the European legislation. ${ }^{26}$

Not until $\sim 40$ years, laws give specific guidance on research with competent adults. The inclusion of patients with restricted cognitive or age-related capacity, however, is heavily regulated on the one hand, but remains vague considering details and definitions as was shown for nine European countries. ${ }^{27}$ In geriatric populations, the percentage of patients suffering from cognitive impairment and decisional incapacity is high, and current regulations only poorly reflect the oftentimes fluent transition from competence to incompetence that is typically encountered in daily practice. ${ }^{28-31}$

\section{Competence and capacity}

Competence (as a legal term) and capacity (as functional description) are integral aspects of IC that, in turn, is an implicit part of one's personality until proven otherwise. Accordingly, the United Nations Educational, Scientific, and Cultural Organization clarifies "... proof of incapacity is required, not proof of capacity. Foolish decisions can be voluntarily made by the most autonomous people and the freedom to do so should not be restricted by imposing overstringent standards of capacity ...." ${ }^{\prime 32}$ Also, current expert panels support this attitude of accepting seemingly unwise decisions without principally questioning capacity as a consequence, ${ }^{5}$ which is regularly the case in daily clinical practice from our experience.

Recognizing evidence of incapacity or incompetence is dependent on the observers' advertence, vulnerability to bias, education, and experiences on the one hand, and on the degree of impairment and the patients' ability/interest to dissimulate on the other hand. Neurological or psychiatric comorbidities aggravate the impression of incompetence. ${ }^{33}$ In this context, it is also important to note that evidence of cognitive impairment does not necessarily imply incompetence. Capability and, in consequence, competence is task specific, and thus dependent on the complexity of the task in proportion to the degree of impairment.

Scores in neuropsychological tests such as the Mini Mental Status Examination (MMSE) tend to correlate with the probability of incompetence. ${ }^{33-36}$ However, they only provide circumstantial evidence, which limits their usefulness as legal basis. Other tests have been specifically designed to assess four dimensions of competence: ${ }^{37}$

1. Understanding (intake and procession of information)

2. Appreciation (evaluation of information in the individual context)

3. Reasoning (comparison of alternatives and realization of consequences)

4. Choice (deciding on one option and communication of the choice). 
However, adequate application of these tests requires exercise and education, as they are prone to a high interobserver variability; furthermore, they tend to be time consuming, which restricts their use in clinical routine.

There are several difficulties in research with elderly patients. One of these is the definition of "elderly". While the term "octogenarians" is specific, the terms "geriatric" and "elderly" are used at random. Some refer to individuals older than 60 years as geriatric, which would probably very much displease them; the WHO states "old is an individual-, culture-, country- and gender-specific term" ${ }^{\prime 38}$ without further clarification. Another approach defines the geriatric patient either by typical multimorbidity and old age (usually $\geq 70$ ) or solely by an age $\geq 80$ due to an age-typical "vulnerability for complications, long-term sequelae, chronicity, and loss of autonomy". 39

We use the term elderly for the population $\geq 65$ years and geriatric for the population $\geq 65$ with a component of frailty due to relevant comorbidity. The European Forum for Good Clinical Practice and the GCP guideline E7 issued by the International Council for Harmonisation (ICH-GCP) E7 give similar advice proposing an age cut-off of 65 years, but stressing the importance of also including patients $\geq 75$ years, ${ }^{6,40,41}$ especially given the importance of biological age compared to numerical age. ${ }^{5}$

In addition to procedural difficulties like potential age limits or obtaining legitimate informed consent, other aspects might complicate research in the elderly. These often are inherent with the target population: the possible influence of comorbidities or concomitant medication, malcompliance or unintentional nonadherence to protocols, high dropout rates, functional and cognitive decline, and mortality. In view of the demographic changes, specific age-adapted treatment approaches will have a significant social and health-economic impact that has to be evaluated by means of research in geriatric patients.

Here, we present the results of an empirical study that analyzes the current practice of conducting studies in geriatric trauma patients with respect to handling of IC, choice of inclusion criteria, and assessment of basic patient characteristics in geriatric populations. Finally, we discuss potential improvements and present, in particular, a proposal for the handling of IC in geriatric populations.

\section{Materials and methods}

In order to evaluate the current situation, a literature search of the PubMed database, comprising a 10-year period from 2005 to 2015, was performed according to the PRISMA guidelines in 07/2016. The aim of the search was to identify studies in the field of orthopedic and trauma surgery that explicitly focus on a geriatric population (paraphrased with the search terms "geriatric", "elderly", and "octogenarians"). The complete search string is shown in the Supplementary material. The resulting articles were screened based on title and abstracts with respect to the following inclusion and exclusion criteria:

Inclusion criteria:

1. Clinical trials including elderly patient populations in orthopedic and trauma surgery

2. Randomized controlled trials (RCTs), pro- and retrospective studies, and case series.

Exclusion criteria:

1. Language other than English, German, or French

2. Unavailability of full text even after contact with the corresponding author

3. Surgical subspecialty other than orthopedic and trauma surgery (exclusion of spinal surgical trials)

4. Biomechanical studies, basic science, study protocols, and cost analyses.

The screening was performed by JSJ under the supervision of FJS. For articles meeting the inclusion criteria, full texts were assessed for the prespecified aspects listed in Table 1 . The items were selected in order to obtain information on the handling of IC, the reported assessment of certain aspects relevant in geriatric populations, and their use as inclusion/exclusion criteria. This assessment was also performed by JSJ under supervision by FJS. Some items were further processed prior to the statistical analysis: countries were grouped by continents, the impact factor was categorized, and the mean age was set to the average of minimal and maximal age in studies not specifically reporting this value. All data were analyzed using SPSS and STATA (Table S1).

\section{Results}

By means of the search strategy reported in the Supplementary material, our search identified 649 articles. After screening based on title and abstract, 183 articles were included in the analysis (see Figure 1 for the PRISMA flowchart). ${ }^{42}$

Table 2 depicts the assessment of certain relevant patient characteristics in geriatric populations as well as their use as inclusion/exclusion criteria. The majority of studies did not report on age-related pathologies or the weight/nutrition status, whereas $51 \%$ reported on a frailty assessment. The use of walking aids as an indirect aspect of a limitation in independence and the living status upon recruitment were 
Table I Screening variables

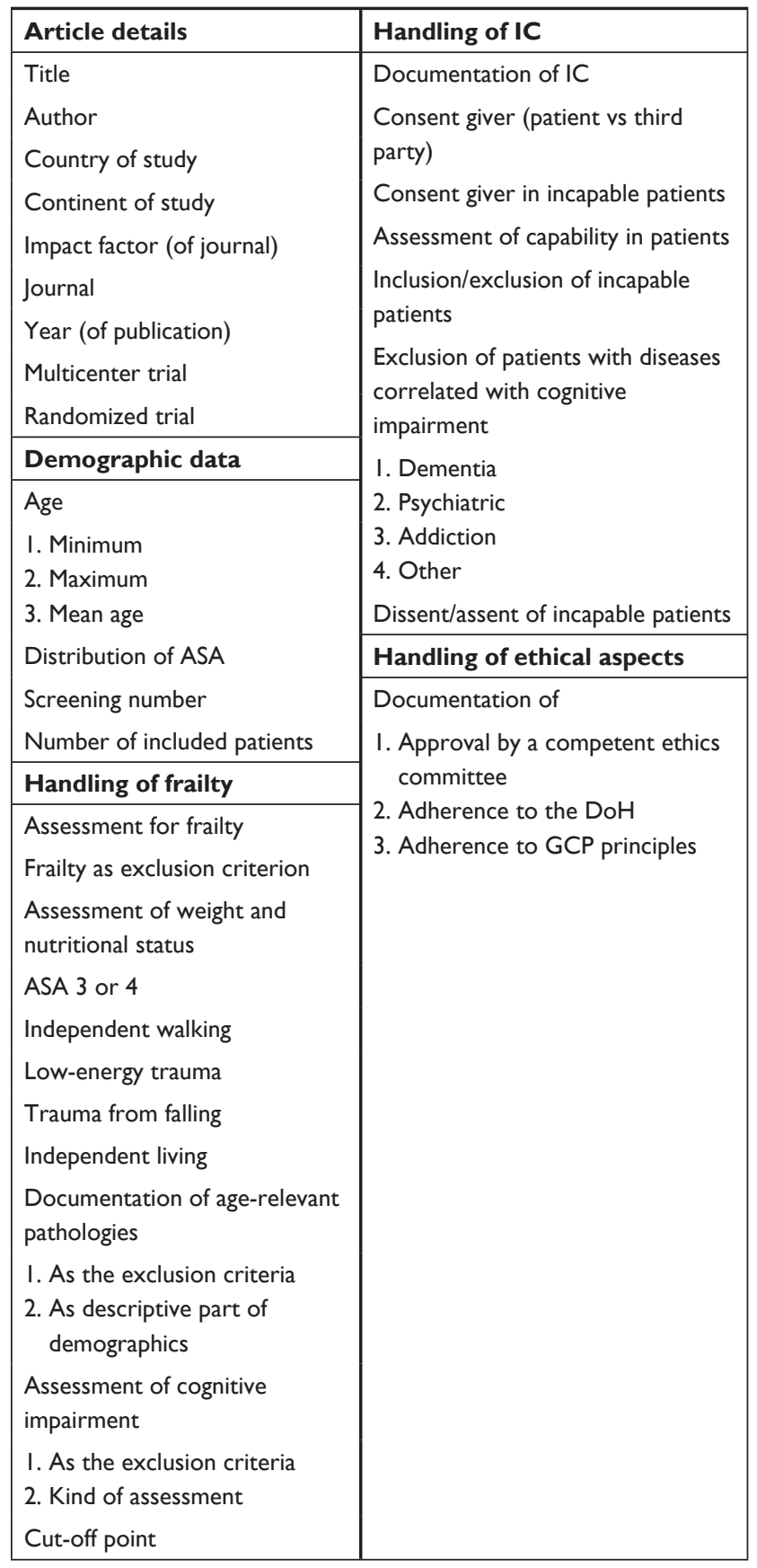

Abbreviations: ASA, American Society of Anesthesiologists; DoH, Declaration of Helsinki; GCP, Good Clinical Practice; IC, informed consent.

reported in about $10 \%$ of all studies. If assessed, frailty, age-related pathologies, incapability of IC, and diagnoses related to cognitive impairment were each used as the exclusion criterion in over one-third of studies.

Half of the studies did not include patients above 90 years and half of the studies had a mean age of $<80$ years, as depicted in Table 3. Similarly, in more than half of the studies, the patients' predominant ASA scores were
ASA 1 or 2, while ASA 3 and 4 patients were not present in $>10 \%$ of all studies.

Table 4 reports the described IC procedures. Only few studies accepted third-party consent, and a minority of articles described a formal assessment of capacity. Of the few articles that document the option of third-party consent, only one acknowledges patients' assent or dissent, which though is a relevant aspect of patient autonomy in the context of decisional incapacity.

Additionally, more formal study characteristics were evaluated as shown in Table 5. Most of the included studies were performed in European countries. Over the years, an increase in the number of studies can be observed. The majority of studies were RCTs; however, only a small proportion was designed as multicenter studies.

In-depth evaluation of these trials revealed a comparison of established techniques or implants in the vast majority of publications. The non-RCT type trials were dominated by case series on similarly established treatment options (Table 6). One RCT and two non-RCTs evaluated experimental interventions.

The principles of GCP were only rarely mentioned in these studies; similarly, the DoH was mentioned in $<20 \%$ and ethical approval in about $80 \%$ of the studies.

Assessing the possible relation between the methodologic complexities of specific trial subtypes and the documented adherence to ethical guidelines or rigorousness of inclusion and exclusion criteria, we indeed found a respective tendency with more frequent mentioning of ethical guidelines and more rigorous patient selection in RCTs, especially when comparing the RCTs to retrospective case series (Table 7).

The reporting of ethical standards did not change over time, as shown in Table 8. The same holds true for the reporting of recruitment rates as an aspect of external validity, with 73 of the 183 studies specifying inclusion and screening rates. The population size of the included studies ranged from 10 to 1,500 participants. While 111 articles did not report an inclusion rate, 49 RCTs and 24 non-randomized trials reported average recruitment rates of $49 \%(4 \%-100 \%$, median 50\%) and 66\% (16\%-100\%, median 69.5\%), respectively.

\section{Discussion}

The analysis of the previously described literature in view of the current regulatory conditions points to a certain potential for improvement at least in the exemplarily chosen area of gerontotraumatology. 


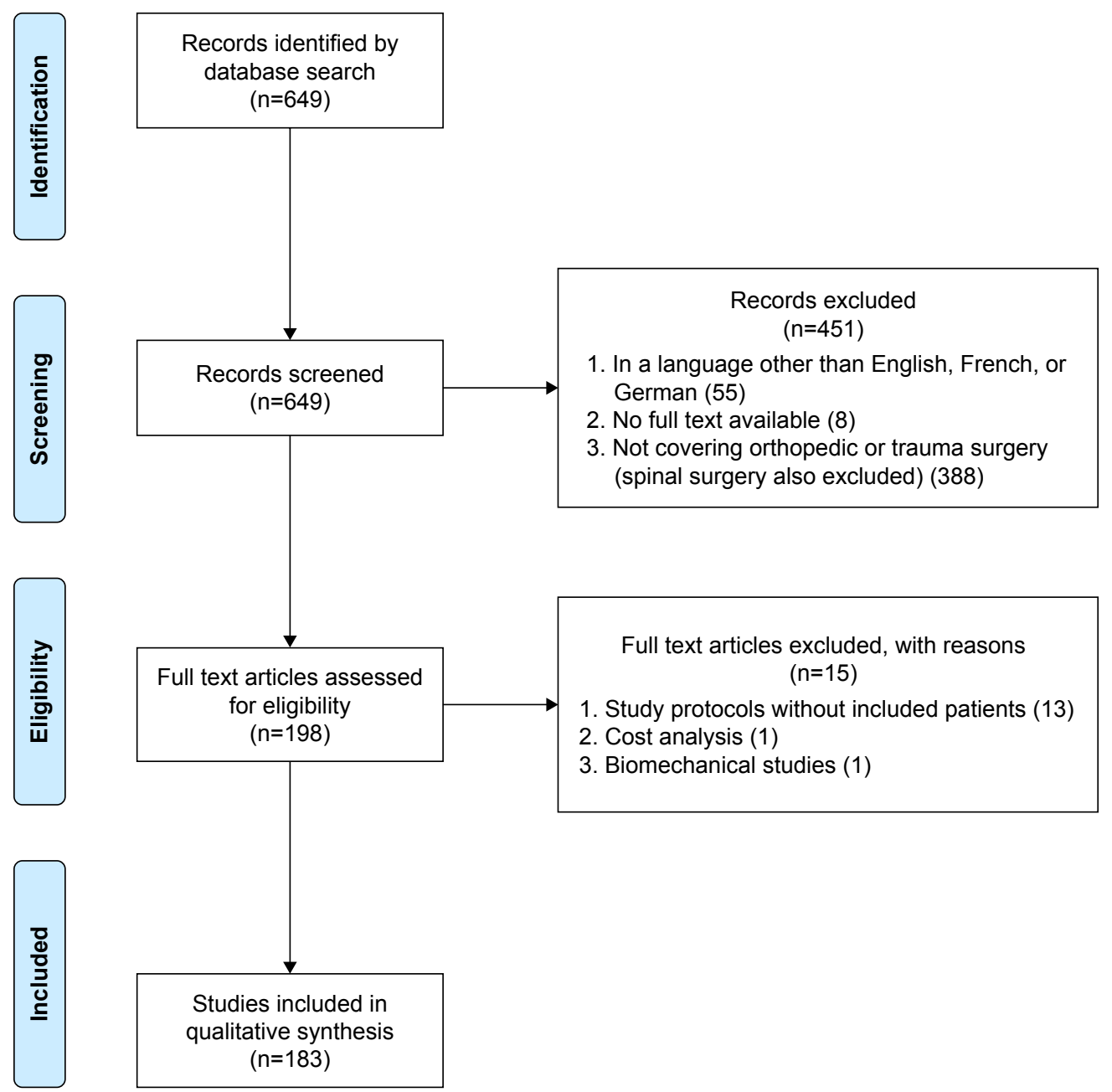

Figure I PRISMA flowchart.

Table 2 Assessment for aspects of frailty and its impact on inclusion practice

\begin{tabular}{|c|c|c|c|c|c|c|c|}
\hline \multirow[t]{2}{*}{ Criterion } & \multirow[t]{2}{*}{ Category } & \multicolumn{3}{|c|}{ Assessment reported } & \multicolumn{3}{|c|}{ Use as exclusion criterion } \\
\hline & & $\mathbf{n}$ & $\mathbf{N}$ & $\%$ & $\mathbf{n}$ & $\mathbf{N}$ & $\%$ \\
\hline Age & Definition of an upper age limit & & & & 20 & 183 & 11 \\
\hline Frailty & & 94 & 183 & 51 & 66 & 183 & 36 \\
\hline \multirow[t]{4}{*}{ Weight/nutritional status } & & 46 & 183 & 25 & & & \\
\hline & Weight & 16 & 183 & 9 & & & \\
\hline & Nutritional status & 4 & 183 & 2 & & & \\
\hline & Both aspects & 26 & 183 & 14 & & & \\
\hline Age-related pathology & & 82 & 183 & 45 & 72 & 183 & 39 \\
\hline Exclusion of patients incapable of IC & & & & & 117 & 183 & 64 \\
\hline \multirow[t]{5}{*}{ Diagnoses related to cognitive impairment } & & & & & 71 & 183 & 39 \\
\hline & Dementia & & & & 57 & & 31 \\
\hline & Psychiatric & & & & 23 & & 12 \\
\hline & Addiction & & & & 25 & & 14 \\
\hline & Other & & & & 11 & & 6 \\
\hline ASA (44) & ASA & 71 & 183 & 39 & & & \\
\hline Independence in walking & & 21 & 183 & 11 & & & \\
\hline Independent living & & 13 & 183 & 7 & & & \\
\hline
\end{tabular}

Abbreviations: ASA, American Society of Anesthesiologists; IC, informed consent. 
Table 3 Distribution of patient characteristics across studies

\begin{tabular}{|l|l|l|l|l|}
\hline \multirow{2}{*}{ Characteristics } & \multicolumn{4}{l}{ Distribution } \\
\cline { 2 - 5 } & n & P I0 & Median & P90 \\
\hline Minimum age & 140 & 50 & 68 & 76 \\
\hline Maximum age & 140 & 79.5 & 89 & 96 \\
\hline Mean age & 160 & 65 & 78 & 84 \\
\hline \% ASA 3 or 4 & 44 & 0 & 35.5 & 87 \\
\hline
\end{tabular}

The failure of most trials to mention adherence to central ethical guidelines such as the DoH or GCP is astonishing. The implied negligence of central research-ethical principles is hardly acceptable for clinical research in potentially vulnerable patient populations, such as the geriatric.

In addition, there seems to be a tendency toward the exclusion of patients based on old age, comorbidities, frailty, or cognitive impairment (ie, "difficult" patients), but without scientific reasoning. This practice of narrow exclusion criteria puts vulnerable populations at risk, while trying to protect them from exploitation. Ultimately, "evidence" on geriatric patients is generated based on patients lacking the typical characteristics of old age, such as frailty, comorbidities, and cognitive impairment. Therefore, the external validity of such "evidence" is highly questionable. The external validity is further jeopardized by low recruitment rates.

Old, ill, frail, and cognitively impaired patients are not only highly vulnerable to exploitation by doctors, researchers, or other perceived authorities, ${ }^{43}$ but also suffer from a lack of evidence-based therapeutic approaches and benefits from medical progress. Therefore, exclusion criteria without scientific or legal necessity should be virtually minimized, thus avoiding potentially hazardous consequences such as increasing the barriers for the inclusion of individual patients or necessitating larger patient samples, given the mean recruitment rate of $50 \%$ and high dropout rates.

It has to be acknowledged though that, especially considering the aspect of legitimate IC, current ethical guidelines for clinical research fail to support the inclusion of mentally impaired patients/subjects through specific and appropriate advice - an effect that is itself ethically problematic. In consequence, the current practice of obtaining IC is heterogeneous, IC is omitted as in $20 \%$ of analyzed trials, or patients are primarily excluded if a straightforward IC seems unrealistic. Clinical research and IC have to be based on the respectful and trustworthy partnership between patient and researchernot unlike that between patient and physician. Therefore, one option for improvement would be the adjustment of the level of required information to the patient's respective cognitive capacity resulting from a general neuropsychological assessment. Flooding patients with 20 aspects (as in ICH-GCP E6 paragraph 4.8.10) ${ }^{44}$ of study conduct renders IC an empty shell. Instead, we propose a stepwise approach in cognitively impaired patients, adapting the extent of imperative

Table 4 Handling of IC

\begin{tabular}{|c|c|c|c|c|}
\hline Characteristic & Category & $\mathbf{n}$ & $\mathbf{N}$ & $\%$ \\
\hline IC as inclusion criterion & & 144 & 183 & 79 \\
\hline \multirow[t]{5}{*}{ Specification of consenting party } & & 138 & & 75 \\
\hline & No description & 45 & & 25 \\
\hline & Patients & 116 & & 63 \\
\hline & Relatives/guardian & 2 & & I \\
\hline & Patient and/or proxies & 20 & & 11 \\
\hline \multirow[t]{6}{*}{ Phrasing of the IC-giving party } & & 19 & 183 & 10 \\
\hline & Legal representative & 5 & & 3 \\
\hline & Proxy & 2 & & 1 \\
\hline & Relative & 9 & & 5 \\
\hline & Relatives or friends & 2 & & $\mathrm{I}$ \\
\hline & Legal representative or caregiver & 1 & & 0.5 \\
\hline \multirow[t]{5}{*}{ Assessment of capacity } & & 17 & 183 & 9 \\
\hline & No documentation & 166 & & 91 \\
\hline & Clinical judgment & 4 & & 2 \\
\hline & Specific assessment of cognitive impairment & 11 & & 6 \\
\hline & Existence of legal representative & 2 & & I \\
\hline Information on the inclusion of incapable patients & & 83 & 183 & 45 \\
\hline Documentation of patients' assent/dissent for third-party IC & & I & 183 & 0.5 \\
\hline
\end{tabular}


Table 5 Study characteristics

\begin{tabular}{|c|c|c|c|c|}
\hline Characteristics & Variables & $\mathbf{n}$ & $\mathbf{N}$ & $\%$ \\
\hline \multirow[t]{34}{*}{ Country/continent } & & & 183 & 100 \\
\hline & Europe & 116 & & 63 \\
\hline & Germany & 19 & & 10 \\
\hline & The Netherlands & 17 & & 9 \\
\hline & Sweden & 15 & & 8 \\
\hline & Norway & 12 & & 7 \\
\hline & Spain & 9 & & 5 \\
\hline & UK & 9 & & 5 \\
\hline & Denmark & 8 & & 4 \\
\hline & Italy & 7 & & 4 \\
\hline & Austria & 4 & & 2 \\
\hline & Greece & 4 & & 2 \\
\hline & Finland & 3 & & 2 \\
\hline & France & 3 & & 2 \\
\hline & Belgium & 2 & & 1 \\
\hline & Switzerland & 2 & & I \\
\hline & Czech Republic & I & & 0.5 \\
\hline & Asia & 47 & & 26 \\
\hline & China & 15 & & 8 \\
\hline & South Korea & 9 & & 5 \\
\hline & Turkey & 7 & & 4 \\
\hline & Taiwan & 6 & & 3 \\
\hline & Israel & 4 & & 2 \\
\hline & Japan & 4 & & 2 \\
\hline & China and Australia & I & & 0.5 \\
\hline & Hong Kong & I & & 0.5 \\
\hline & Australia/Oceania & 4 & & 2 \\
\hline & Australia & 3 & & 2 \\
\hline & New Zealand & I & & 0.5 \\
\hline & $\begin{array}{l}\text { USA/Canada/ } \\
\text { South America }\end{array}$ & 17 & & 9 \\
\hline & USA & 11 & & 6 \\
\hline & Canada & 3 & & 2 \\
\hline & Brazil & 2 & & I \\
\hline & USA and Canada & I & & 0.5 \\
\hline \multirow[t]{12}{*}{ Year of publication } & & & 183 & 100 \\
\hline & 2005 & 17 & & 9 \\
\hline & 2006 & 8 & & 4 \\
\hline & 2007 & 14 & & 8 \\
\hline & 2008 & 13 & & 7 \\
\hline & 2009 & 13 & & 7 \\
\hline & 2010 & 19 & & 10 \\
\hline & 2011 & 23 & & 13 \\
\hline & 2012 & 21 & & 11 \\
\hline & 2013 & 21 & & 11 \\
\hline & 2014 & 27 & & 15 \\
\hline & 2015 & 7 & & 4 \\
\hline
\end{tabular}

(Continued)
Table 5 (Continued)

\begin{tabular}{|c|c|c|c|c|}
\hline Characteristics & Variables & $\mathbf{n}$ & $\mathbf{N}$ & $\%$ \\
\hline Randomized & & 131 & 183 & 72 \\
\hline \multirow[t]{3}{*}{ Multicenter } & Yes & 19 & 183 & 10 \\
\hline & No & 113 & 183 & 62 \\
\hline & Not mentioned & 51 & 183 & 28 \\
\hline \multirow[t]{6}{*}{ Impact factor classes } & & 181 & 183 & 100 \\
\hline & $0-1.00$ & 40 & & 22 \\
\hline & $1.01-2.00$ & 61 & & 34 \\
\hline & $2.01-3.00$ & 46 & & 25 \\
\hline & $3.01-5.00$ & 27 & & 15 \\
\hline & $5.01-10.99$ & 7 & & 4 \\
\hline $\begin{array}{l}\text { Ethical approval } \\
\text { mentioned }\end{array}$ & & 145 & 183 & 79 \\
\hline $\begin{array}{l}\text { Ethical board } \\
\text { mentioned }\end{array}$ & & 139 & 183 & 76 \\
\hline GCP & & 7 & 183 & 4 \\
\hline $\mathrm{DoH}$ & & 34 & 183 & 19 \\
\hline Low-energy trauma & & 31 & 183 & 17 \\
\hline \multirow[t]{2}{*}{ Trauma after falling } & & 20 & 183 & 11 \\
\hline & & plo & Median & p90 \\
\hline Population size & $\begin{array}{l}\text { Number of included } \\
\text { patients }\end{array}$ & 24 & 75 & 319 \\
\hline Recruitment rate & $\begin{array}{l}\text { Number of included } \\
\text { patients/number of } \\
\text { screened patients }\end{array}$ & 0.15 & 0.58 & 0.95 \\
\hline
\end{tabular}

Abbreviations: DoH, Declaration of Helsinki; GCP, Good Clinical Practice.

information to both the 1) trial-related risks and 2) the difference between the proposed treatments (eg, conservative vs surgical compared to two surgical approaches or different types of splints) to the (assessed) abilities of the patient. This approach is similar to the concept of "low-intervention clinical trials" elaborated in Regulation (EU) No 536/2014, ${ }^{45}$ which suggests "less stringent rules" for the execution of these trials that are immensely important for the assessment of standards of care. This rule would apply for the vast majority of the above-evaluated trials. Its application could increase overall recruitment rates and, therefore, enhance the external validity of the results.

The propositions below though outreach the concept of "low-intervention clinical trials" as well as the relatively vague guidelines issued by, for example, the Swiss Academy of Medical Sciences, for example, on "care and treatment of people with dementia (2017)" or "medical treatment and care of people with disabilities (2008, updated 2013)". ${ }^{46}$ These guidelines stress the importance of research in geriatric patient populations and give advice on reaching treatment decisions, but fail to give practical guidance for IC to research. 
Table 6 Subtypes of trials

\begin{tabular}{|c|c|c|c|c|c|}
\hline Characteristics & Category & $\mathbf{n}$ & $\begin{array}{l}\mathrm{N} \\
\text { subtype }\end{array}$ & $\begin{array}{l}\mathbf{N} \\
\text { total }\end{array}$ & $\%$ \\
\hline \multirow[t]{7}{*}{ Randomized trials } & & & $|3|$ & 183 & 71.6 \\
\hline & Comparison of established approaches or marketed implants & $4 \mathrm{I}$ & & $|3|$ & 32 \\
\hline & Comparison of established surgical techniques' & 26 & & $13 \mid$ & 19 \\
\hline & Comparison of established substances for anesthesia or analgesia & 9 & & $|3|$ & 8 \\
\hline & Comparison of established anesthesiologic techniques ${ }^{2}$ & 13 & & $|3|$ & 10 \\
\hline & Comparison of perioperative interventions to standard care $^{3}$ & 41 & & 131 & 31 \\
\hline & Experimental new product vs standard care & 1 & & & \\
\hline \multirow[t]{7}{*}{ Non-randomized trials } & & & 52 & 183 & 29 \\
\hline & Analysis of established approaches or marketed implants & 21 & $\begin{array}{l}-5 \mathrm{nRCT} \\
-9 \mathrm{pCS} \\
-7 \mathrm{rCS}\end{array}$ & 52 & 40 \\
\hline & Analysis of established techniques & 4 & $-4 \mathrm{pCS}$ & 52 & 8 \\
\hline & Analysis of experimental techniques & 2 & $-2 \mathrm{nRCT}$ & 52 & 4 \\
\hline & Analysis of established substances for anesthesia or analgesia & 4 & $\begin{array}{l}-3 \text { pCS } \\
-1 \text { rCS }\end{array}$ & 52 & 8 \\
\hline & Trials on scoring & 4 & $\begin{array}{l}-1 \mathrm{nRCT} \\
-2 \mathrm{pCS} \\
-1 \mathrm{rCS}\end{array}$ & 52 & 9 \\
\hline & Analysis of perioperative interventions & 17 & $\begin{array}{l}-9 \mathrm{nRCT} \\
-8 \mathrm{pCS}\end{array}$ & 52 & 32 \\
\hline
\end{tabular}

Notes: 'E.g. open reduction and internal fixation vs. arthroplasty, internal vs. external fixation, ${ }^{2}$ e.g. spinal vs. general anästhesia, nerve block vs. iv analgesia, ${ }^{3}$ e.g. orthogeriatric complex treatment yes/no, specific physiotherapeutic regimen yes/no.

Abbreviations: $\mathrm{nRCT}$, non-randomized trials; pCS, prospective case series; rCS, retrospective case series.

As described previously, there are four dimensions of competence:

1. Information considering the necessary decision can be understood (dimension of understanding).

2. The effect and consequences deriving from the choice of one possible alternative can be weighed against those deriving from the choice of another (dimension of appreciation).

3. Information can be rationally interpreted in the context of a coherent system of norms and values (dimension of reasoning).
4. A choice can be communicated (dimension of choice).

The measurement of these abilities poses a certain challenge in daily practice, since repeat-back interviews or the MacArthur Competence Assessment Tool is time intensive and requires specific experience and training of the assessor. The MMSE, in contrast, is already widely used, available, and validated in many languages with high inter-rater reliability. ${ }^{47,48}$ The correlation between MMSE or cognitive function and competence is admittedly only loose, though several studies describe thresholds that are clearly associated with clear deficits in competence $(\leq 23)$, limited

Table 7 Mention of ethical guidelines and potential restriction of inclusion per trial type

\begin{tabular}{|c|c|c|c|c|c|c|c|c|}
\hline & $\begin{array}{l}\text { Ethics } \\
\text { GCP } \\
\text { DoH }\end{array}$ & Ethics & GCP & DoH & $I C^{a}$ & Frailty $^{b}$ & Capability ${ }^{c}$ & $\begin{array}{l}\text { Cognitive } \\
\text { impairment }^{\mathrm{d}}\end{array}$ \\
\hline & $\%$ e & $\%$ e & $\%$ e & $\%{ }^{\mathrm{e}}$ & $\%$ e & $\%$ e & $\%$ e & $\%$ e \\
\hline RCT I30 & 4 & 86 & 5 & 21 & 84 & 40 & 69 & 46 \\
\hline$R C T_{\text {experimental }} \mathrm{I}$ & 0 & 100 & 0 & 0 & 100 & 0 & 0 & 0 \\
\hline Prospective case series 26 & 0 & 62 & 0 & 8 & 73 & 35 & 65 & 31 \\
\hline Retrospective case series 9 & 0 & 33 & 0 & 11 & 33 & 0 & 0 & 0 \\
\hline $\begin{array}{l}\text { Prospective non-randomized } \\
\text { trial } 15\end{array}$ & 7 & 73 & 7 & 20 & 73 & 33 & 60 & 13 \\
\hline $\begin{array}{l}\text { Prospective non-randomized } \\
\text { trial }_{\text {experimental }} 2\end{array}$ & 0 & 100 & 0 & 50 & 50 & 0 & 50 & 50 \\
\hline
\end{tabular}

Notes: ${ }^{a} \mathrm{C} C$ required for inclusion. ${ }^{\mathrm{b}} \mathrm{Frailty}$ as the exclusion criterion. ${ }^{\mathrm{C} C a p a b i l i t y}$ as a prerequisite for inclusion. ${ }^{\mathrm{d} D i a g n o s e s}$ associated with cognitive impairment as the exclusion criterion. $\%$ of the specific trial subtype total given below the type.

Abbreviations: DoH, Declaration of Helsinki; GCP, Good Clinical Practice; IC, informed consent; RCT, randomized controlled trial. 
Table 8 Distribution of inclusion rate and ethics

\begin{tabular}{|l|l|l|l|l|l|l|}
\hline Year & $\begin{array}{l}\text { Ethical } \\
\text { board (\%) }\end{array}$ & $\begin{array}{l}\text { GCP } \\
(\%)\end{array}$ & $\begin{array}{l}\text { DoH } \\
(\%)\end{array}$ & $\begin{array}{l}\text { Reporting of } \\
\text { analyzed patient } \\
\text { number (\%) }\end{array}$ & $\begin{array}{l}\text { Reporting of } \\
\text { recruitment and } \\
\text { screening rates (\%) }\end{array}$ & $\begin{array}{l}\text { Number of } \\
\text { publications }\end{array}$ \\
\hline 2005 & $12(7 I)$ & $\mathrm{I}(6)$ & $3(18)$ & $17(100)$ & $5(29)$ & 17 \\
\hline 2006 & $6(75)$ & $\mathrm{I}(13)$ & $\mathrm{I}(13)$ & $8(100)$ & $3(38)$ & 8 \\
\hline 2007 & $10(7 \mathrm{I})$ & $\mathrm{I}(7)$ & $2(14)$ & $14(100)$ & $8(57)$ & 14 \\
\hline 2008 & $10(77)$ & $\mathrm{I}(8)$ & $3(23)$ & $13(100)$ & $2(15)$ & 13 \\
\hline 2009 & $13(100)$ & $0(0)$ & $3(23)$ & $13(100)$ & $7(31)$ & 13 \\
\hline 2010 & $16(84)$ & $0(0)$ & $5(26)$ & $19(100)$ & $7(30)$ & 19 \\
\hline 2011 & $18(78)$ & $1(4)$ & $5(21)$ & $22(96)$ & $10(48)$ & 23 \\
\hline 2012 & $16(76)$ & $0(0)$ & $5(24)$ & $19(90)$ & $10(48)$ & 21 \\
\hline 2013 & $18(86)$ & $0(0)$ & $3(14)$ & $20(95)$ & $12(44)$ & 21 \\
\hline 2014 & $19(70)$ & $2(7)$ & $2(7)$ & $25(93)$ & $5(71)$ & 27 \\
\hline 2015 & $7(100)$ & $0(0)$ & $2(29)$ & $7(100)$ & 7 \\
\hline
\end{tabular}

Abbreviations: DoH, Declaration of Helsinki; GCP, Good Clinical Practice.

competence (23-26), and high probability of preserved competence $(>26){ }^{28,34-36}$

Patients with a legal representative can be considered for inclusion in a trial if all of the following statements apply:

1. The patients show no signs of refusal (ie, give their assent).

2. The legal representative consents.

Patients with an MMSE score of 23, but without an appointed legal representative can be considered for inclusion in a trial, if all of the following statements apply:

1. The patients show no signs of refusal (ie, give their assent).

2. The risk of the trial (ie, both treatments) is negligible.

3. The patient's relatives or close relations consent (according to the hierarchy on potential substitute-decision makers imposed by the Swiss Civil Code) ${ }^{49}$

Patients with an MMSE score between 23 and 26 can be considered for inclusion in clinical trials if all of the following statements apply:

1. The patient consents.

2. The patient understands that he/she can refuse to take part without consequences.

3. The patient understands that other treatment methods are available and that those can be chosen independently of the proposed trial.

4. The patient understands the principles of the proposed procedures, their risks, and benefits.

5. The patient understands that neither he/she nor the treating physician can choose the treatment method (in case of randomization).

6. The patient's relatives or close relations agree (this oral agreement has the aim of supporting the patient, rather than a legal function).

Patients with an MMSE score over 26 are considered for inclusion independently of the above-mentioned measures.
In order to protect our patients, we propose to include additional third-party consent if competence can be assumed, but MMSE is conspicuous, or if there are indeed signs of incompetence.

In addition, we propose addressing the following further aspects:

First, the perception of the environment might differ in frail elderly patients from the perception in younger patients, given a potential impairment of vision, hearing, adaptation to a new environment, and so on. ${ }^{50-52}$ Indeed, Inouye and Charpentier ${ }^{53}$ have described precipitating factors for delirium: the use of physical restraints, malnutrition, more than three medications added, use of bladder catheter, and any iatrogenic event. These could be interpreted as modifiable external risk factors that should be optimized along with factors such as nutrition, electrolyte disturbances, inter-current infection, and so on, which have been identified as predisposing factors. ${ }^{54-56}$ As part of a respectful partnership, patients should be made as comfortable as possible before being asked to give consent. Overstimulation should be avoided by reducing the surrounding noise, adapting the light, avoiding disturbance, inclusion of close relations, and sufficient analgesia (measured via visual analog scale). ${ }^{57}$ First, as part of a specific gerontotraumatologic approach, we try to reduce the time in the emergency ward, minimize tubes and lines and, if possible, operate on all patients within a maximum of 24 hours. Furthermore, for clinical research, pictures and big font size for written information should be used to ensure legibility. Second, we suggest a re-evaluation that should take place at least 6 hours after the initial inclusion. To ascertain the understanding of the above-mentioned points, the evaluation with standardized repeat-back ${ }^{58}$ or a brief assessment of capacity ${ }^{59}$ should be 
considered intermittently to ensure proper conduct, especially in an initial phase and for complex interventional trials. This approach might be hampered by the development of preoperative delirium that has been reported to range from $4.4 \%$ to $33 \%,{ }^{54}$ depending on the presence of predisposing and precipitating risk factors. We, therefore, consider a close collaboration with family, friends, and close relations essential in order to capture patients' wishes and life concepts and respect them in clinical research. In case of inter-current cognitive deterioration, the willingness to continue participation in the trial is ascertained at every follow-up visit.

Third, on a more general basis, we also suggest including healthy representatives of the respective target population or patient organizations as reviewers for the protocol, the IC material, and the process of the trial.

These measures ultimately lead to the introduction of the concept of "shared decision making" between patient and researcher. In the realm of treatment decisions, this principle has been welcomed even on the most prestigious forums of medicine, ${ }^{60}$ and it allows a more individualized process of obtaining the patients' understanding and response to a recommendation. If we honestly aim at specifically and legitimately including geriatric patients in research and keeping research in these patients attractive, we have to propose, possibly in analogy to the concept of shared decision making, guidelines that are practicable and meet the spirit of the doctrine of IC rather than the letters of bureaucratic forms.

\section{Conclusion}

Scientific and medical progress for geriatric patients is currently stagnating, with only little research conducted in this specific population. Literal adherence to guidelines and regulations leads to cumbersome inclusion procedures that discourage researchers and do not protect, but rather disrespect, the right of cognitively impaired and, therefore, vulnerable elderly or geriatric patients to access relevant research. The situation could be improved by adjusting the level of required information to the patients' cognitive capacity after a simple neuropsychological assessment with certain additional safety measures before final inclusion. The introduction of the concept of shared decision making could additionally help to rectify the currently somewhat precarious research practice. Common sense and explicit respect for the needs of the individual seem to more accurately meet the spirit of the doctrine of IC than following bureaucratic procedures to the letter.

\section{Disclosure}

The authors report no conflicts of interests in this work.

\section{References}

1. Cherubini A, Del Signore S, Ouslander J, Semla T, Michel JP. Fighting against age discrimination in clinical trials. J Am Geriatr Soc. 2010; 58(9):1791-1796.

2. Broekhuizen K, Pothof A, de Craen AJ, Mooijaart SP. Characteristics of randomized controlled trials designed for elderly: a systematic review. PLoS One. 2015;10(5):e0126709.

3. Le Quintrec JL, Bussy C, Golmard JL, Hervé C, Baulon A, Piette F. Randomized controlled drug trials on very elderly subjects: descriptive and methodological analysis of trials published between 1990 and 2002 and comparison with trials on adults. J Gerontol A Biol Sci Med Sci. 2005;60(3):340-344.

4. van Deudekom FJ, Postmus I, van der Ham DJ, et al. External validity of randomized controlled trials in older adults, a systematic review. PLoS One. 2017;12(3): $\mathrm{e} 0174053-\mathrm{e} 0174058$.

5. Wrobel P, Dehlinger-Kremer M, Klingmann I. Ethical challenges in clinical research at both ends of life. Drug Inf J. 2011;45(1): 89-105.

6. Diener L, Hugonot-Diener L, Alvino S, et al. Guidance synthesis. Medical research for and with older people in Europe: proposed ethical guidance for good clinical practice: ethical considerations. J Nutr Health Aging. 2013;17(7):625-627.

7. Witham MD, McMurdo ME. How to get older people included in clinical studies. Drugs Aging. 2007;24(3):187-196.

8. Toerien M, Brookes ST, Metcalfe C, et al. A review of reporting of participant recruitment and retention in RCTs in six major journals. Trials. 2009;10(1):1-12.

9. Davies L, Cook J, Price A, Beard D. What are the methodological challenges in the design and conduct of orthopaedic randomised controlled trials comparing surgery and non-operative interventions? A systematic review. Trials. 2017;18(Suppl 1):O65.

10. Percival T. Medical Ethics or A Code of Institutes and Precepts, Adapted to the Professional Conduct of Physicians and Surgeons. Manchester: S. Russell; 1803.

11. American Medical Association. Code of Medical Ethics of the American Medical Association Originally Adopted at the Adjourned Meeting of the National Medical Convention in Philadelphia. Chicago: American Medical Association Press. 1897. Available from: https:// babel.hathitrust.org/cgi/pt?id=ien.35558005316472; view=1up;seq=3. Accessed January 22, 2019.

12. Beauchamp TL. Informed consent: its history, meaning, and present challenges. Camb Q Healthc Ethics. 2011;20(4):515-523.

13. Will JF. A brief historical and theoretical perspective on patient autonomy and medical decision making: part II: the autonomy model. Chest. 2011;139(6):1491-1497.

14. Lombardo PA. Phantom tumors and hysterical women: revising our view of the Schloendorff case. J Law Med Ethics. 2005;33(4):791-801.

15. Anweisung an die Vorsteher Der Kliniken, Polikliniken und sonstigen Krankenanstalten über medizinische Eingriffe zu anderen ALS zu diagnostischen, Heil- und Immunisierungszwecken vom 29. Dezember 1900. Zentralblatt für die gesamte Unterrichtsverwaltung Preußen. 1901. Available from: http://goobiweb.bbf.dipf.de/. Accessed December 18, 2018.

16. Mitscherlich A, Mielke F. editors. Medizin Ohne Menschlichkeit. Dokumente Des Nürnberger Ärzteprozesses. Frankfurt a.M.: Fischer Taschenb.; 1989.

17. Tröhler U R-TS, editor. The Nuremberg Code: The Proceedings in the Medical Case, the Ten Principles of Nuremberg, and the Lasting Effect of the Nuremberg Code. Aldershot, UK: Ashgate Publishing Ltd; 1998.

18. World Medical Association. Declaration of Helsinki. Ethical Principles for Medical Research Involving Human Subjects Adopted by the 18th WMA General Assembly, Helsinki, Finland, June 1964. Available from: http//www.cirp.org/library/ethics/helsinki/. Accessed January 22, 2019.

19. Beecher HK. Ethics and clinical research. NEngl J Med. 1966;274(24): 1354-1360. 
20. Pappworth MH. Human Guinea Pigs: Experimentation on Man. Harmondsworth: Penguin Books; 1969.

21. CDC [homepage on the Internet]. U.S. Public Health Service Syphilis Study at Tuskegee. Available from: http://www.cdc.gov/tuskegee/ timeline.htm. Accessed July 8, 2018.

22. Public law 93-348-Juli 12, 1974 88-Stat. National Research Act. Available from: http://history.nih.gov/research/downloads/PL93-348. pdf. Accessed July 8, 2018.

23. HHS.gov [homepage on the Internet. The Belmont Report, Ethical Principles and Guidelines for the Protection of Human Subjects of Research. The National Commission for the Protection of Human Subjects of Biomedical and Behavioral Research. Available from: http://www.hhs.gov/ohrp/humansubject. Accessed April 18, 1979.

24. ICH Harmonised Tripartite Guideline. Guideline for good clinical practice E6(R1). ICH Harmonised Tripartite Guideline. 1996;1996(4):i-53. Available from https://www.ich.org/fileadmin/Public_Web_Site/ ICH_Products/Guidelines/Efficacy/E6/E6_R1_Guideline.pdf. Accessed January 22, 2019

25. Women $\mathrm{P}, \mathrm{Fe}-\mathrm{H}$, Involved N. Code of federal regulations title 45 department of health and Human services part 46 Protection of human subjects. 2009. Available from: https://www.hhs.gov/ohrp/sites/default/ files/ohrp/policy/ohrpregulations.pdf. Accessed January 22, 2019.

26. Commission Directive $91 / 507 /$ EEC of 19 July 1991 modifying the Annex to Council Directive 75/318/EEC on the approximation of the laws of member States relating to analytical, pharmacotoxicological and clinical standards and protocols in respect of the test. Available from: https://publications.europa.eu/en/publication-detail/-/ publication/98ea0b12-c69c-4608-a406-001e48ed29a5/language-en. Accessed January 22, 2019.

27. Koch HG, Reiter-Theil SHH, editors. Informed Consent in Psychiatry European Perspectives of Ethics, Law and Clinical Practice. BadenBaden: Nomos Verlagagesellschaft; 1997.

28. Kim SYH, Appelbaum PS, Jeste DV, Olin JT. Proxy and surrogate consent in geriatric neuropsychiatric research: update and recommendations. Am J Psychiatry. 2004;161(5):797-806.

29. Duguet AM, Boyer-Beviere B. Consent to medical research of vulnerable subjects from the French point of view: the example of consent in research in the case of Alzheimer disease. Med Law. 2011;30(4):613-627.

30. Gainotti S, Fusari Imperatori S, Spila-Alegiani S, et al. How are the interests of incapacitated research participants protected through legislation? An Italian study on legal agency for dementia patients. PLoS One. 2010;5(6):e11150.

31. Galeotti F, Vanacore N, Gainotti S, et al. How legislation on decisional capacity can negatively affect the feasibility of clinical trials in patients with dementia. Drugs Aging. 2012;29(8):607-614.

32. United Nations educational, scientific and cultural organization, report of the International bioethics Committee of UNESCO (IBC) on consent, social and human sciences sector, division of ethics of science and technology, bioethics section, SHS/EST/CIB08. Available from: https://unesdoc. unesco.org/ark:/48223/pf0000178124. Accessed January 22, 2019.

33. Walaszek A. Clinical ethics issues in geriatric psychiatry. Psychiatr Clin North Am. 2009;32(2):343-359.

34. Kim SYH, Caine ED. Utility and limits of the Mini Mental State Examination in evaluating consent capacity in Alzheimer's disease. Psychiatr Serv. 2002;53(10):1322-1324.

35. Karlawish J. Measuring decision-making capacity in cognitively impaired individuals. Neurosignals. 2008;16(1):91-98.

36. Marson DC, Ingram KK, Cody HA, Harrell LE. Assessing the competency of patients with Alzheimer's disease under different legal standards. A prototype instrument. Arch Neurol. 1995;52(10): 949-954.

37. Schaefer LA. MacArthur Competence Assessment Tools. In: Kreutzer JS, DeLuca J, Caplan B. (eds) Encyclopedia of Clinical Neuropsychology. Springer, New York, NY. 2011.

38. World Health Organization. Men, Ageing and Health. Geneva: World Health Organization. 2001:1-63.

39. Riem S, Hartwig E, Hartwig J. Alterstraumatologie. Orthopädie und Unfallchirurgie up2date. 2012;7(03):187-205.
40. (GMWP)EGMWP.MedicalResearchForandWithOlderPeopleinEurope. 2013:1-27. Available from: http://efgcp.organica.eu.com/EFGCP/ documents/EFGCPGMWPResearchGuidelinesFinaledited2013052770. pdf. Accessed January 21, 2019.

41. International Council for Harmonization. E7 Studies in Support of Special Populations: Geriatrics Questions \& Answers Current Version E7 $Q \&$ As Document History. ICH. 2010. Available from: https://www. fda.gov/downloads/drugs/guidancecomplianceregulatoryinformation/ guidances/ucm189544.pdf. Accessed January 22, 2019.

42. PRISMA transparent reporting of systematic reviews and meta-analyses [homepage on the Internet]. Available from: http://www.prismastatement.org/. Accessed December 20, 2018.

43. Ivashkov Y, van Norman GA. Informed consent and the ethical management of the older patient. Anesthesiol Clin. 2009;27(3):569-580.

44. European Medicines Agency [homepage on the Internet]. CPMP/ ICH/135/95, ICH topic e 6 (R1) Guideline for Good Clinical Practice; 2002. Available from: www.ema.europa.eu/pdfs/human/ich/013595en. pdf. Accessed July 8, 2018.

45. The European Parliament and the Council of the European Union. Regulation (EU) No 536/2014 of the European Parliament and of The Council of 16 April 2014 on Clinical Trials on Medicinal Products for Human Use, and Repealing Directive 2001/20/EC.; 2014. Available from: https://ec.europa.eu/health/sites/health/files/files/eudralex/vol-1/ reg_2014_536/reg_2014_536_en.pdf. Accessed January 22, 2019.

46. SAMW/ASSM medical-ethical guidelines. Medical treatment and care of people with disabilities. 2008. (updated 2013). Available from: https://www.samw.ch/en/Publications/Medical-ethical-Guidelines. html. Accessed July 8, 2018.

47. Folstein MF, Folstein SE, McHugh PR. "Mini-mental state". A practical method for grading the cognitive state of patients for the clinician. J Psychiatr Res. 1975;12(3):189-198.

48. Cullen B, O'Neill B, Evans JJ, Coen RF, Lawlor BA. A review of screening tests for cognitive impairment. J Neurol Neurosurg Psychiatry. 2007;78(8):790-799.

49. Bundesversammlung D, Eidgenossenschaft DS. Schweizerisches Zivilgesetzbuch. 2011. Available from: https://www.admin.ch/opc/ de/classified-compilation/19070042/201901010000/210.pdf. Accessed January 25, 2019.

50. Inouye SK, Westendorp RGJ, Saczynski JS. Delirium in elderly people. Lancet. 2014;383(9920):911-922.

51. Homeier D. Aging: physiology, disease, and abuse. Clin Geriatr Med. 2014;30(4):671-686.

52. Conroy S, Elliott A. The frailty syndrome. Medicine. 2017;45(1):15-18.

53. Inouye SK, Charpentier PA. Precipitating factors for delirium in hospitalized elderly persons. JAMA. 1996;275(11):852.

54. Schuurmans MJ, Duursma SA, Shortridge-Baggett LM, Clevers GJ, Pel-Littel R. Elderly patients with a hip fracture: the risk for delirium. Appl Nurs Res. 2003;16(2):75-84.

55. Smith TO, Cooper A, Peryer G, Griffiths R, Fox C, Cross J. Factors predicting incidence of post-operative delirium in older people following hip fracture surgery: a systematic review and meta-analysis. Int J Geriatr Psychiatry. 2017;32(4):386-396.

56. Blondell RD, Powell GE, Dodds HN, Looney SW, Lukan JK. Admission characteristics of trauma patients in whom delirium develops. Am J Surg. 2004;187(3):332-337.

57. Hjermstad MJ, Fayers PM, Haugen DF, et al. Studies comparing numerical rating scales, verbal rating scales, and visual analogue scales for assessment of pain intensity in adults: a systematic literature review. J Pain Symptom Manage. 2011;41(6):1073-1093.

58. Fink AS, Prochazka AV, Henderson WG, et al. Enhancement of surgical informed consent by addition of repeat back: a multicenter, randomized controlled clinical trial. Ann Surg. 2010;252(1):27-36.

59. Jeste DV, Dunn LB, Palmer BW, et al. A collaborative model for research on decisional capacity and informed consent in older patients with schizophrenia: bioethics unit of a geriatric psychiatry intervention research center. Psychopharmacology. 2003;171(1):68-74.

60. Barry MJ, Edgman-Levitan S. Shared decision making - the pinnacle of patient-centered care. NEngl J Med Overseas Ed. 2012;366(9):780-781. 


\section{Supplementary material Search term}

((()(surgery[MeSH Major Topic]) OR traumatology[MeSH Major Topic]) OR sur-gery[Title/Abstract]) OR traumatology[Title/Abstract])) AND ((()((geriatric[MeSH
Major Topic]) OR elderly[MeSH Major Topic]) OR octogenarian[MeSH Major Topic]) OR geri-atric[Title/ Abstract]) OR elderly[Title/Abstract]) OR octogenarian[Title/ Abstract]).

Table SI Items extracted from each article and analyzed variables

\begin{tabular}{|c|c|c|}
\hline Item & Description, definition & Value, categories \\
\hline Title & Title & \\
\hline Authors & Authors & \\
\hline Country of study & In which country was the study performed & \\
\hline Continent of study & $\begin{array}{l}\text { In which continent the study was performed } \\
\text { according to the "country of study" }\end{array}$ & $\begin{array}{l}-999=\text { Missing } \\
\text { I= Europe } \\
2=\text { Asia } \\
3=\text { Africa } \\
4=\text { North America } \\
5=\text { South America } \\
6=\text { Australia and Oceania } \\
7=\text { Australasia }\end{array}$ \\
\hline \multicolumn{3}{|l|}{ Impact factor } \\
\hline Journal & Journal & \\
\hline Year & Year & \\
\hline Screening number & Number of patients screened & \\
\hline patients_included & Number of patients included & \\
\hline MINALTER & Minimal age reported & \\
\hline MAXALTER & Maximum age reported & \\
\hline weight_nutritional & $\begin{array}{l}\text { Weight and/or nutritional status reported as } \\
\text { BMI, or specific blood work }\end{array}$ & $\begin{array}{l}0=\text { not reported } \\
\text { I }=\text { yes, only weight } \\
2=\text { yes, only nutritional status } \\
3=\text { yes, both }\end{array}$ \\
\hline Frailty & Was there any assessment for frailty reported? & $\begin{array}{l}0=\text { no } \\
\mathrm{I}=\text { yes }\end{array}$ \\
\hline frail_excluded & Were frail patients excluded from the studies? & $\begin{array}{l}0=\text { no } \\
1=\text { yes } \\
2=\text { not mentioned }\end{array}$ \\
\hline ASA & Was the ASA reported? & $\begin{array}{l}0=\text { no } \\
\mathrm{I}=\text { yes }\end{array}$ \\
\hline ASA_3_4 & $\begin{array}{l}\text { When yes, what percentage of patients was at } \\
\text { least ASA } 3 \text { or } 4 \text { ? }\end{array}$ & Percentage \\
\hline independent_walking & Independent walking reported & $\begin{array}{l}0=\text { no } \\
\mathrm{I}=\text { yes }\end{array}$ \\
\hline low_energy_trauma & $\begin{array}{l}\text { Were patients included, who were injured } \\
\text { during low-energy trauma like falling? }\end{array}$ & $\begin{array}{l}0=\text { no } \\
\mathrm{I}=\text { yes } \\
2=\text { not mentioned }\end{array}$ \\
\hline percent_suffer_trauma_falling & $\begin{array}{l}\text { What percentage of patients suffered from } \\
\text { trauma during falling? }\end{array}$ & Percentage \\
\hline exc_age_pathology & $\begin{array}{l}\text { Were patients with typically age-related } \\
\text { pathology excluded? }\end{array}$ & $\begin{array}{l}0=\text { no } \\
I=\text { yes } \\
2=\text { not mentioned }\end{array}$ \\
\hline kind_pathology & If yes, what kind of pathology? & \\
\hline
\end{tabular}


Table SI (Continued)

\begin{tabular}{|c|c|c|}
\hline Item & Description, definition & Value, categories \\
\hline Independent_living & $\begin{array}{l}\text { Was independent living patient mentioned or } \\
\text { reported? }\end{array}$ & $\begin{array}{l}0=\text { no } \\
I=\text { yes } \\
2=\text { not mentioned }\end{array}$ \\
\hline inexmeasure & $\begin{array}{l}\text { Was there an inclusion/exclusion criterion } \\
\text { based on a formal assessment of cognitive } \\
\text { impairment? Was the assessment named? } \\
\text { (INEXMEASURE) }\end{array}$ & $\begin{array}{l}0=\text { no } \\
I=\text { yes }(\text { named }) \\
2=\text { yes (not named/defined) }\end{array}$ \\
\hline Tools_Cog_Imp & $\begin{array}{l}\text { Which tool was used for measurement of } \\
\text { cognitive impairment? }\end{array}$ & $\begin{array}{l}\text {-999= Fehlender Wert } \\
\text { I= Short MMSE/MMSE } \\
2=\text { AMT } \\
3=\text { SIS } \\
4=6-\text { CIT } \\
5=\text { CDT } \\
6=\text { Mini-Cog } \\
7=\text { GPCPG } \\
8=\text { Other }\end{array}$ \\
\hline Value & $\begin{array}{l}\text { If yes, which measurements, instruments, and } \\
\text { cut-off points were used for each tool? }\end{array}$ & $\begin{array}{l}-999=\text { Fehlender Wert } \\
0=\text { no } \\
\mathrm{I}=\text { yes }\end{array}$ \\
\hline consent_required & $\begin{array}{l}\text { Was consent required as the inclusion } \\
\text { criterion? }\end{array}$ & $\begin{array}{l}0=\text { no } \\
I=\text { yes } \\
2=\text { unknown }\end{array}$ \\
\hline consentgiver & Who gave consent? & $\begin{array}{l}0=\text { not described } \\
\mathrm{I}=\text { Patient himself } \\
2=\text { Relative/guardian } \\
3=\text { Patient or relative and so on }\end{array}$ \\
\hline Person & $\begin{array}{l}\text { How was the person who gave the IC in } \\
\text { incapable patients phrased? }\end{array}$ & $\begin{array}{l}I=\text { legal representative } \\
2=\text { proxy } \\
3=\text { trustee } \\
4=\text { relative } \\
5=\text { relatives or friends } \\
7=\text { legal representative or caregiver }\end{array}$ \\
\hline howincap & $\begin{array}{l}\text { Is any information on how the capability of } \\
\text { patients was assessed? }\end{array}$ & $\begin{array}{l}0=\text { no } \\
I=\text { yes, clinical judgment } \\
2=\text { yes, assessment of cognitive impairment } \\
3=\text { yes, existence of legal representative }\end{array}$ \\
\hline Randomized & Was the study a randomized study? & $\begin{array}{l}0=\text { no } \\
\mathrm{I}=\text { yes }\end{array}$ \\
\hline Multicenter & Was the study a multicenter trial? & $\begin{array}{l}0=\text { no } \\
\mathrm{I}=\text { yes } \\
2=\text { unknown }\end{array}$ \\
\hline Ethics & Is ethical approval of the study mentioned? & $\begin{array}{l}0=\text { no } \\
\mathrm{I}=\text { yes }\end{array}$ \\
\hline ethical_board & What kind of ethical board? & $\begin{array}{l}\text { I= local ethical board (eg, hospital ethics } \\
\text { committee, institutional review board) } \\
2=\text { regional ethical board } \\
3=\text { other }\end{array}$ \\
\hline GCP & GCP mentioned? & $\begin{array}{l}0=\text { no } \\
\mathrm{I}=\text { yes }\end{array}$ \\
\hline DECHEL & $\begin{array}{l}\text { Is following the Declaration of Helsinki } \\
\text { mentioned? }\end{array}$ & $\begin{array}{l}0=\text { no } \\
\mathrm{I}=\text { yes }\end{array}$ \\
\hline
\end{tabular}


Table SI (Continued)

\begin{tabular}{|c|c|c|}
\hline Item & Description, definition & Value, categories \\
\hline inexclude & $\begin{array}{l}\text { Do the inclusion/exclusion criteria of the study } \\
\text { explicitly address patients who are incapable } \\
\text { to give IC? }\end{array}$ & $\begin{array}{l}\text { I= incapable patients are explicitly excluded } \\
\text { (additionally to the necessity of IC) } \\
2=\text { incapable patients are implicitly excluded } \\
\text { due to necessity of IC } \\
3=\text { incapable patients are not primarily } \\
\text { excluded } \\
4=I C \text { is not (even) part of the inclusion/ } \\
\text { exclusion criteria } \\
5=\text { not mentioned }\end{array}$ \\
\hline INEXDIAG & $\begin{array}{l}\text { Were patients with diagnoses related to } \\
\text { cognitive impairment excluded? }\end{array}$ & $\begin{array}{l}0=\text { no } \\
\mathrm{I}=\text { yes } \\
2=\text { not mentioned }\end{array}$ \\
\hline $\begin{array}{l}\text { DEMENTIA/PSYCHIATRIC/ADDICTION/ } \\
\text { OTHER_A }\end{array}$ & $\begin{array}{l}\text { If yes, which type of diagnosis is mentioned? } \\
\text { (Dementia) }\end{array}$ & $\begin{array}{l}0=\text { no } \\
\mathrm{I}=\text { yes }\end{array}$ \\
\hline INFINCAP & $\begin{array}{l}\text { Do we have any information about whether } \\
\text { incapable patients were included in the study } \\
\text { or not? We screened for signs of incapability, } \\
\text { such as cognitive impairment, dementia, } \\
\text { caregivers, and so on }\end{array}$ & $\begin{array}{l}0=\text { no } \\
\mathrm{I}=\text { yes }\end{array}$ \\
\hline included_patients & If yes, were incapable patients included? & $\begin{array}{l}\mathrm{I}=\text { not incapable } \\
2=\text { incapable are included }\end{array}$ \\
\hline incapable_assent_dissent & $\begin{array}{l}\text { In incapable patients, when consent was given } \\
\text { by a third party, did the patient give his assent } \\
\text { or dissent? }\end{array}$ & $\begin{array}{l}0=\text { not } \text { mentioned } \\
\mathrm{I}=\text { dissent } / \text { assent } \text { mentioned }\end{array}$ \\
\hline dissent_assent_consequences & $\begin{array}{l}\text { If yes, was dissent/assent recognized? What } \\
\text { were the consequences? }\end{array}$ & $\begin{array}{l}0=\text { no consequences } \\
\mathrm{I}=\text { dissent accepted } \rightarrow \text { exclusion of patient } \\
2=\text { ethical board request }\end{array}$ \\
\hline
\end{tabular}

Note: Reported signifies a presentation of quantitative results, whereas mentioned is used for a categorical documentation of specific items without quantifications.

Abbreviations: BMI, body mass index; IC, informed consent; MMSE, Mini Mental Status Examination; AMT, Abbreviated Mental Test; SIS, six-item screener; 6-CIT, Six Item Cognitive Impairment Test; CDT, Clock Drawing Test; GPCPG, general practitioner assessment of cognition.

\section{Publish your work in this journal}

Clinical Interventions in Aging is an international, peer-reviewed journal focusing on evidence-based reports on the value or lack thereof of treatments intended to prevent or delay the onset of maladaptive correlates of aging in human beings. This journal is indexed on PubMed Central, MedLine,
CAS, Scopus and the Elsevier Bibliographic databases. The manuscript management system is completely online and includes a very quick and fair peer-review system, which is all easy to use. Visit http://www.dovepress. com/testimonials.php to read real quotes from published authors. 